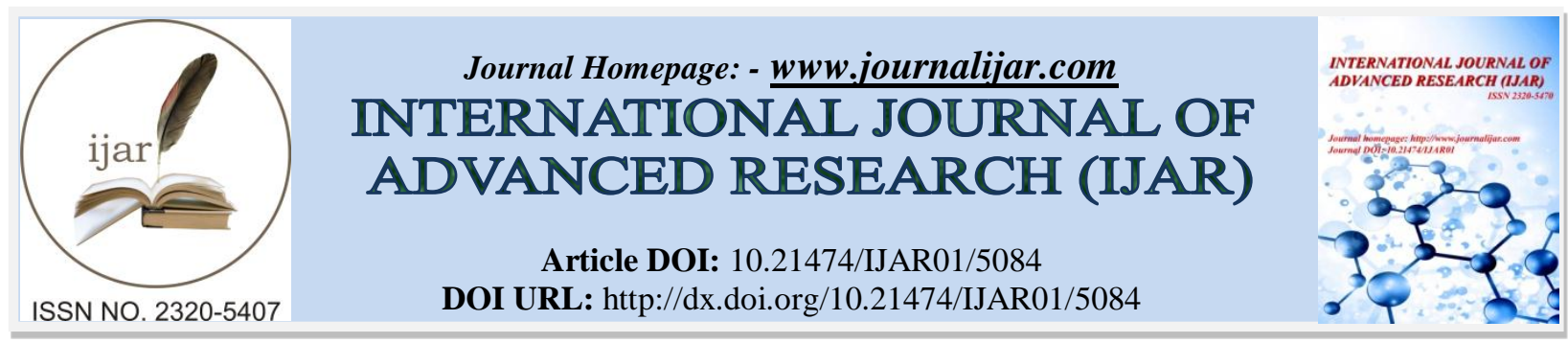

RESEARCH ARTICLE

\title{
IMPROVING PEOPLE KNOWLEDGE ABOUT NATURAL RESOURCE CONSERVATION BY DEVELOPING INSTRUCTIONAL PACKAGE ON ECOLOGICAL CONCEPTS RELATED TO SASI CULTURE.
}

Stevin Melay and I Made Putrawan.

\section{Manuscript Info}

Manuscript History

Received: 06 June 2017

Final Accepted: 08 July 2017

Published: August 2017

Key words:-

SASI culture, Instructional package,

Ecological concepts, Treatment group.

\begin{abstract}
This research is aimed at finding out whether instructional package development based on ecological concepts related to SASI culture is able effectively to improve people knowledge about natural resource conservation in Maluku Province. For this purpose, Research and Development has been applied by involving 30 people as sample, each for treatment and control group. Instrument for measuring people knowledge has been developed in true-false format with reliability was .897. Research results revealed that there was significant difference of people knowledge between post and pre-test in treatment group, between treatment and control post-test groups, and between treatment and control group gain-scores. These indicated that instructional package was able to improve effectively people knowledge about natural resource conservation. SASI culture has been proven to be one of traditional heritages which influence people way of live in how to live harmoniously with nature. It has been also strengthened by integrating it with ecological concepts in an instructional package. This product could be disseminated for young generation as what expected by sustainable development, especially among Maluku community.
\end{abstract}

Copy Right, IJAR, 2017,. All rights reserved.

\section{Introduction:-}

Environmental destruction will cause changes in the environment, so the environment decreases the function of the provider of the need to support human life. If this is not resolved soon it will ultimately affect the disruption of human welfare. Environmental damage that occurs due to the exploitation of natural resources to meet human needs without regard to environmental sustainability. This environmental destruction has disrupted natural processes, resulting in many natural functions being disrupted.

Odum (2005: 2) states that in primitive society, all individuals needed to know their environment that is, to understanding the forces of nature and the plants and animals around them to survive. The success of a development process is determined by the availability of Natural Resources both in quantity and quality (Putrawan, 2014: 52). Gifford Pinchot (1910), defines natural resources as a commodity and quality found in nature. Walujo (2002: 252), states that conservation can be defined as a continuity between the research (study it), the use (use it) and the protection (save it). Conservation is important because it is not only intended for the preservation of various biological resources but also conserves the genetic resources, species and ecosystems that are essential to preserve the present and future life. 
SASI is one of the conservation activities in the form of culture that has been done by the people in Maluku. Zulfikar Judge and Marissa Nurizka (2008: 56), described that SASI is a prohibition to harvest certain resources (marine and terrestrial biodiversity) within the stipulated timeframe. If SASI is implemented, then the people is prohibited from picking certain fruits on land and taking certain results from the sea during the period set by the village government.

According to Keraf (2014: 8) sound-friendly behavior with nature arises from a new paradigm and worldview of the universe as an integrated whole system of life that is integrated with one another. A new holistic and ecological way of view of the universe, since it recognizes that man is only one entity in the great continuum of the whole universe. Putrawan, (2014: 4) in his book says that when the understanding of the basic concepts of ecology is increasing, the more positive the attitude towards the environment and this will lead to a more positive behavior in interacting with the environment.

If it is believed that human activities have a vital role in destructing our environment, therefore the target of any activities would be human being. Education is a tool, in this case, which its aim at improving the awareness, knowledge, attitudes even personality or behavior of human being. Education has the power to change, in a long time, human behavior through his or her knowledge, attitudes or personality. Those process would be running with process of learning, socialization, and internalization which could take long time until achieve the goal, Putrawan (2015:325).

Pribadi (2010: 124) explaining that knowledge is a reflection of the experience and the external world that is influenced by cultural factors, language, beliefs, interaction with others, direct learning and modeling. The guidance, discovery, learning experience, model, training, beliefs and knowledge possessed previously greatly affect the success of individuals in the learning process. Furthermore, Kuhlthau (2010) asserts that the discovery learning with counseling to acquire deeper knowledge through various sources of information is called guided inquiry.

Formally in the world of education, high school and university students regard teacher and lecturer as a source of direct learning. This is because the teacher and lecturer who convey various knowledge directly in the classroom, while the people get knowledge from sources of information through media such as TV, Radio, Books, brochures, and posters contextually. This is in line with what was stated by Department of National Education (2002), which explains in seven main component of contextual approach one of its component that is learning people. Therefore, this research aims to develop one of the learning resources for the people in the form of SASI Culture-based Conservation Package in Maluku. That is why research problems could be formulated into two parts (1) how to develop an instructional package based on ecological conservation related to SASI culture in improving people knowledge about natural resource and (2) does this instructional package could be able to improve people knowledge about natural resource effectively?

\section{Research Methodology:-}

This research is a development research based on the design developed by Borg and Gall (2007) and refers to the instructional design model of Dick and Carey (2015) to produce INSTRUCTIONAL package of SASI Culture Based Conservation package. Not all stages of research on the design of research and development referenced implemented. This happens because the purpose of the use of Package is not on the formal education environment that involves students as research targets, but the target is to the people.

In this study, Waai village in Central Maluku district was selected as a treatment group. The package was given to the people to be studied for 3 weeks. While Negeri Lama village in Ambon City was selected as a control group that was not given the package. There were 30 respondents in each group so in total there were 60 respondents. Effectiveness test is done in the form of test consisting of pre-test and post-test by using instrument test consisting 35 items by true-false format with reliability .897 .

Data of effectiveness test result in the value of pre-test and post-test in both groups were analyzed by using t-test to know whether there is difference of value between treatment group and control group on post-test result. Before done test-t test result data, then done first test normality and test homogeneity to research instrument consisting of 40 item. After tested and analyzed, then 5 items are declared invalid or drop so that there are only 35 items on the research instrument. The purpose of this study is to produce a Package that can be used by the people as a source of learning to increase their knowledge about the conservation of natural resources. 
Tests on the effectiveness of teaching materials are done through experimental methods with pre-test, post-test control and treatment group design. The design description of the experiment is as follows:

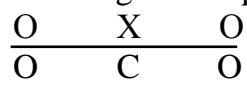

Information :

$\mathrm{X}=$ Treatment

$\mathrm{C}=$ Control

$\mathrm{O}=$ Observation

\section{Research Findings:-}

INSTRUCTIONAL "SASI Culture for Conservation" is the title of the Package produced in this study. The development of an Instructional Package in the form of a Package was developed on the basis of instructional development steps. The package contains materials on ecology and its scope, conservation, SASI culture and SASI culture in ecological concepts. Materials in each section has been developed based on the extent and coverage of the material that is considered important to be learned by the people. The extent of the material is tailored to the purpose of the development of packages as well as the extent of people knowledge, as the learning patterns of the people are different from those of formal education in schools and colleges.

Based on descriptive statistics calculation, it was found that post-test means for treatment was 33.2 and 31.2 for control group. Means gain score between treatment and control group was 4.9 and 3.17 respectively. It could be seen, in detail, on table 1 below.

Table 1:- Pre-test score, Post-test and Gain score data from treatment groups and control groups related to people knowledge about conservation of natural resources.

\begin{tabular}{|c|c|c|c|}
\hline \multirow{3}{*}{ Score pre-test } & \multirow{3}{*}{\begin{tabular}{|l|} 
Score pre-test Amount \\
\end{tabular}} & \multicolumn{2}{|l|}{ Group } \\
\hline & & Treatment & Control \\
\hline & & 30 & 30 \\
\hline \multirow{6}{*}{ Score pre-test } & Means & 28.27 & 28.0 \\
\hline & Mode & 29 & 30 \\
\hline & Median & 29 & 28 and 29 \\
\hline & Span of score & $22-34$ & $20-33$ \\
\hline & Standard deviation & 3.06 & 3.2 \\
\hline & Variance & 9.36 & 10.24 \\
\hline \multirow[t]{7}{*}{ post-test score } & Total post-test score & 30 & 30 \\
\hline & Means & 33.2 & 31.2 \\
\hline & Mode & 34 & 31 dan 33 \\
\hline & Median & 34 & 31 \\
\hline & Span of score & $30-35$ & $25-35$ \\
\hline & Standard deviation & 1.71 & 2.41 \\
\hline & Variance & 2.92 & 5.81 \\
\hline \multirow[t]{7}{*}{ Gain score } & Amount & 30 & 30 \\
\hline & Means & 4.9 & 3.17 \\
\hline & Mode & 5 & 3 \\
\hline & Median & 5 & 3 \\
\hline & Span of score & $1-13$ & $1-8$ \\
\hline & Standard deviation & 2.65 & 1.41 \\
\hline & Variance & 7.02 & 1.99 \\
\hline
\end{tabular}

In addition to descriptive analysis, there was also an analysis to find out the difference of values from treatment group and control group using t-test. Based on t-test analysis obtained value result of pre-test and post-test of control group is 12.25. In the treatment group the results of pre-test and post-test obtained value 10.19. Result of post-test of treatment group and control group was 3.71, then value gain score treatment and control group was 3.21. While the value of $\mathrm{t}$-tab obtained is 1.69 against all value with significant. 
Therefore, based on different test results as described above in accordance with the data shown in Table 2, it can be concluded that there was a significant difference of knowledge between the treatment group and the control group so that based on the existing criteria the null hypothesis was rejected. This meant that instructional packages were read by the people as a source of effective learning to increase people knowledge about conservation of natural resources.

Table 2:- Different Test Analysis results between Treatment group and control group on conservation of natural resources.

\begin{tabular}{|c|c|c|}
\hline \multirow[t]{2}{*}{ Test group } & \multicolumn{2}{|c|}{ Test statistics } \\
\hline & t-hit & t-tab \\
\hline Pre-test and post-test control group & 12.25 & \multirow[b]{4}{*}{1.69} \\
\hline Pretest and post-test treatment group & 10.19 & \\
\hline Post-test group treatment and control & 3.71 & \\
\hline Gain score test group Treatment and control & 3.21 & \\
\hline
\end{tabular}

$$
* * \mathrm{p}<0.05
$$

Means difference between pre-test and post-test scores of control and treatment groups is shown in graphical form as shown in figure 1. Therefore, it could be seen that the pre-test of control group and treatment group has no significant difference, meaning that both groups have pre-test value which was almost similar to the hypothesis was that two groups have the same entry-behavior. Post-test values in both groups experienced an increase, and there was a difference between the post-test and control group values. For treatment group the value was higher than the control group.

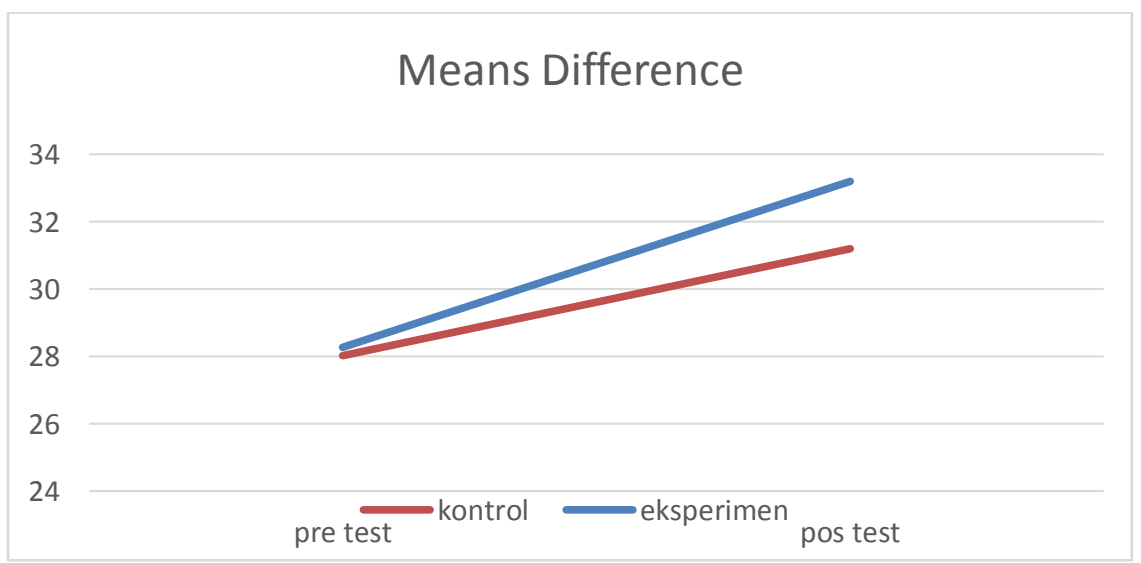

Figure 1:- Differences in means pre-test and post-test of treatment group and control group

\section{Discussion:-}

Knowledge is usually seen as a necessary prerequisite for one's behavior and is considered essential for a successful action, Frick (2004: 1597). Hegel in Putrawan (2015: 327) states that scientific knowledge and human thought in general is the process of transforming from Think-In-Itself to Think-For-Us, from the material nature to something that is beneficial to us. That is, what is not understood at one stage will be explained. This can be seen from the knowledge of ecological conservation owned by the public in the of Waai village which is implemented in the form of SASI culture as a manifestation of the existing culture in the Maluku People as a unity of indigenous peoples.

To improve the knowledge and actions of the people to maintain the existing natural resources in the form of SASIbased cultural conservation is done by utilizing instructional Package as one of the sources of knowledge. Ahmed Djoghlaf in Alcorn (2010: 5) states traditional knowledge requires a comprehensive approach to use in biodiversity conservation. According to Nur (2016: 326), the wisdom of local culture as a product of tribal (or multiethnic) totality has been tested for its existence and relevance. Local cultural wisdom has links to all aspects including environmental aspects.

Hungerford \& Volk (1990) explains, traditional thinking in the field of environmental education is that we can change behavior by making people more aware of the environment and the problems. Research conducted by 
Setyawati, et al (2013: 35) states that the Teaching Materials for Environmental Education Character at the State University of Semarang as one form of instructional package is a necessity in realizing understanding and awareness raising on various environmental issues that are currently happening as well as Stimulus to increase student knowledge.

In the current era in which the development must hold sustainable principles, then the people is expected to have a good level of knowledge in utilizing natural resources that exist around it. Hungerford \& Volk (1990), suggests that If environmental issues are to be an integral part of instructions design to change behavior, instructions must go beyond an awareness of knowledge of issues. Students must be given the opportunity to develop the sense of ownership and empowerment so that they are fully invested in an environmental sense and promoted to become responsible, active citizens.

Afgan, et.al (2010: 28) knowledge is defined as "physiological result of perception and learning and reasoning". In contrast to information, knowledge requires organizational structure of facts with respective attributes reflecting specific properties and processing. Still according to Afgan, et.al (2010: 30) a sustainable knowledge society has to meet a number of diverse criteria. Among these are: sustainability discourse, economic models, characteristics of the emerging knowledge society.

SASI's cultural-based conservation ecology instructional package, developed with its general framework as follows: Exploration of Environmental Phenomena, Strengthening concepts on ecology and conservation, Ecology and Scope, Conservation, SASI Culture in the context of conservation of natural resources. In the early part was explored environmental phenomena related to the concept of conservation ecology. At each end of the material is also delivered Moral messages related to the material on the parts that exist. It is intended that readers (the public) can easily understand the message contained in the description of Conservation Ecology Teachers' materials.

\section{Conclusion:-}

It was found that there was significant difference of people knowledge between post and pre-test in treatment group, between treatment and control post-test groups, and between treatment and control group gain-scores. Those findings indicated that instructional package was able to improve effectively people knowledge about natural resource conservation. SASI culture has been proven to be one of traditional heritages which influence people way of live in how to live harmoniously with nature. It has been also strengthened by integrating it with ecological concepts in an instructional package. If it is expected that people of Maluku would have a more positive responsible environmental behavior, therefore their knowledge would be improved by disseminating and socializing this product effectively. This product could be also disseminated for young generation as what expected by sustainable development, especially among Maluku people.

\section{References:-}

1. Alcorn, Janis. Indigenous Peoples and Conservation. MacArthur Foundation Conservation White Paper Series | 2010.

2. Depdiknas. (2002). Pendekatan kontekstual (Contextual Teaching and Learning (CTL)). Jakarta: Departemen Pendidikan Nasional.

3. Dick, Walter. et. al. The Systematic Design Of Instruction. Eight Edition. The United States of America. 2015.

4. Eko Baroto Walujo. Gatra Etnobotani Eboni \{Diospyros celebica Bakh. Balitbang Botani, Puslitbang Biologi LIPI Bogor. Berita Biologi, Volume 6, Nomor 2. Agustus, 2002 Edisi Khusus.

5. Borg, Walter R. at.al. Educational Research: an introduction. Eighth Edition. Printed in the United States of America. 2007.

6. Hungerford, Harold R., and Trudi L. Volk. "Changing learner behavior through environmental education." The journal of environmental education 21.3 (1990): 8-21.

7. Jacqueline Frick a, et.al. Environmental knowledge and conservation behavior: exploring prevalence and structure in a representative sample. Personality and Individual Differences 37 (2004) 1597-1613.

8. Judge, Zulfikar. et al. Peranan Hukum Adat SASI Laut dalam melindungi Kelestarian Lingkungan di desa Eti Kecamatan Seram Barat Kabupaten Seram Bagian Barat. Lex Jurnalica Vol. 6 No.1, Hal 30-61, 2008.

9. Kuhlthau, C.C. (2010). Guided inquiry: school librariesin the 21st century. International association of school librarianship, vol 16, number 1, pp. 17-28.

10. Mitchell, Bruce, et al. Resource and Environmental Management. Gadjah Mada University Press, 2010. 
11. Naim Hamdija Afgan. et. Al The Knowledge Society: A Sustainability Paradigm. CADMUS. Volume 1. Number 1 October 2010.

12. Nur, Ramli. Local Culture Wisdom In The Process Of Social Interaction Of Malay Ethnic In Batu Bara Regency. ISLAMICA: Journal of Islamic Studies Volume 10 No. 2, March 2016; P-ISSN: 1978-3183; E-ISSN: 2356-2218; 325-348.

13. Odum, Eugena P. 2005. Fundamentals of Ecology. COPYRIGHT, a division of Thomson Learning, Inc.

14. Personal, Benny A. Pendekatan Konstruktivistik Dan Pengembangan Bahan Ajar Pada Sistem Pendidikan Jarak Jauh. Jurnal Pendidikan Terbuka dan Jarak Jauh, Volume 11, Nomor 2, September 2010, 117-128.

15. Pinchot, Gifford. 1910. The Fight for Conservation. New York: Doubleday, Page, \& Co.

16. Putrawan, I Made. Konsep-konsep Dasar Ekologi Dalam Berbagai Aktivitas Lingkungan. Penerbit Alfabeta Bandung, 2014.

17. Putrawan, I Made. Measuring New Environmental Paradigm Based on Students' Knowledge About Ecosystems and Locus of Control. Eurasian Journal of Mathematics, Science \& Technology Education, 2015,11 (2), 325 333.

18. Sonny, A Keraf. Filsafat Lingkungan Hidup; Alam Sebagai Sebuah Sistem Kehidupan. PT. Kanisius, 2014. h. 8. 